Historic, Archive Document

Do not assume content reflects current scientific knowledge, policies, or practices. 

GOOD FIELD SEEDS

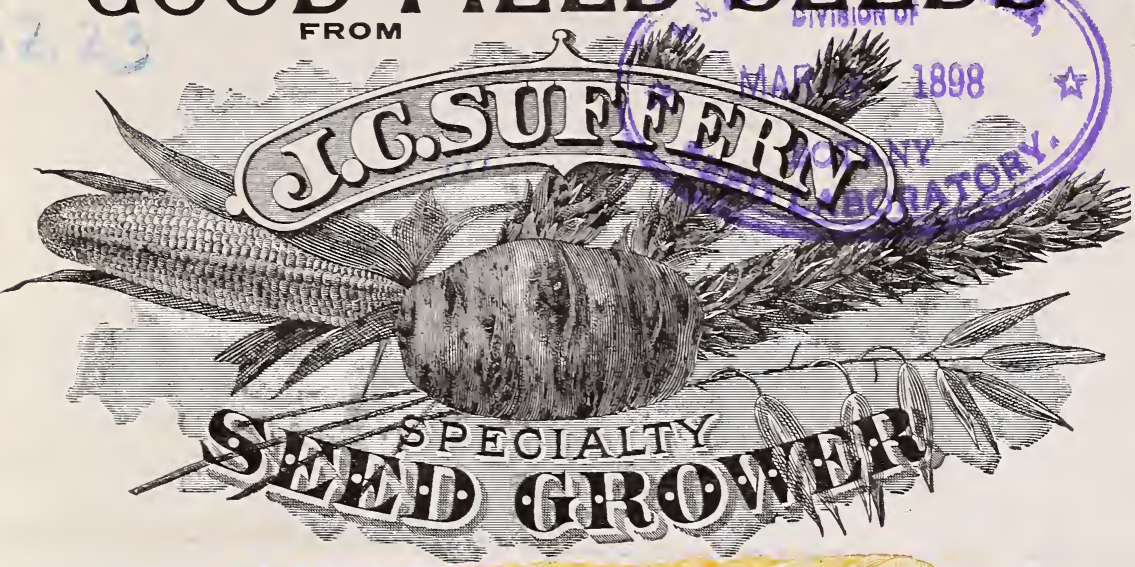

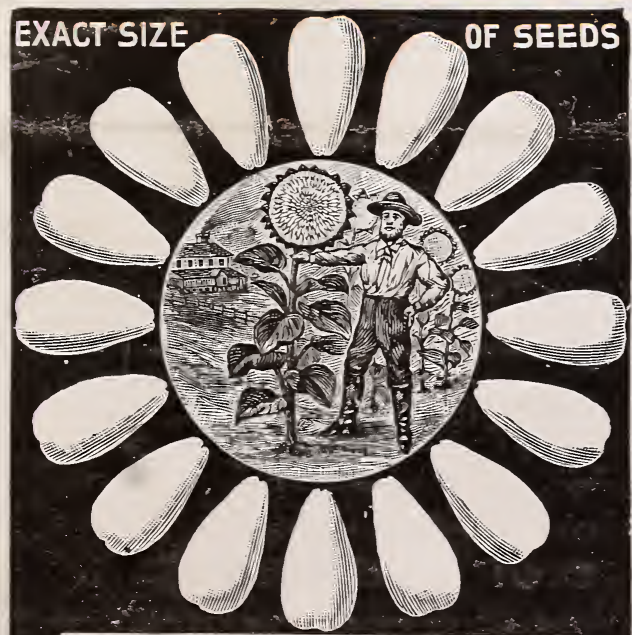

WHITE BEAUTY SUNFLOWER.

\section{CHANGE YOUR SEED}

Some farmers keep sowing old runout varieties, because they have the seed handy. They do not figure up their loss by so doing.

WHEN LETTERS are mailed in Ohio, Indiana, Missouri, and Kansas, to-day, fast mail generally delivers them to me on to-morrow.

HON. ISAAC MORTON said "That

the product of one quart of a variety of wheat brought from North Carolina in 1845, had in nine years benefitted the farmers of Preble county, $O$., alone, more than $\$ 100.000 .00$ by the gain over what they would have had, if they had continued raising-the old varieties.

Address

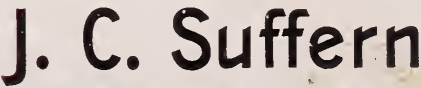 SEED GROWER}

VOORHIES ILLINOIS. 
Confidence is the foundation of all business transactions. That is just what I want,-your confidence. My previous record entitles me to it. I ask your fullest investigation of my reputation in the past, my financial standing at the present time, and my ability to perform what I promise in the future. If you have never yet ordered seeds from me, then you naturally desire to know whether it is safe to send me money. And you have a right to know. I refer you for information to (in making inquiries, always enc ose stamped envelope addressed to yourself, for their reply to your inquiry): First National Bank, Bement, 1llinois. Postmaster, Voorhies, Ill. Pacific Express Agent, Voorhies, Ill.

\section{DIRECTIONS FOR ORDERING.}

ORDEREARLY. And then you will be sure to have the seed just when you want it. Send your OADER EARL1. order to=day. Before you lose my address. Unless my trade is very much larger than I expect, I will have plenty of seed of the varieties herein advertised until June 15th.

MV TERMS are strictly cash with the Order. Send money by registered letter, money order, IIIMS or by Chicago or New York draft. At my risk. Money order office, Voorhies, Illinois. No seed sent C, O. D. Personal checks on country banks not wanted, as it costs me 20 cents each to collect them. Express money orders for sale at all express offices, are cheap, and very safe. SHIPPING. I am located on the Wabash and I. D. \& W. R'ys. Midway between Chicago and St. Kansas City, and Omaha. Be sure and state what route you wish seeds sent by. When no instructions are given, I shall use my best judgment in the matter.

THIS PRICE LIST. Do you wish to receive it regularly, from time to time, as it comes revising my list of addresses. And do not wish to mail it to any one to whom it is of no use. Please show it to your neighbors, and then put it away with your valuable papers. So you can get it quickly, when you wish to order. Tell all your friends about my seeds. And get them to order with you. If this price list should become misplaced, or lost, write at once, for another copy, which will be sent in haste. If you do not receive my 1899 Catalogue, you can order from this one, as prices will be about the same.

WARRANTING While I exercise the greatest care to have all my seeds pure and reliable, it is WARRANIING. hereby mutually agreed between myself and the purchaser, that I do not warrant any of my seeds. And am not in any respect, liable or responsible for the seeds sold by me. Or for any failure thereof in any respect. Of course I sell seeds of good vitality. And as pure as the greatest care can keep them. See page 7 .

\section{SEAMLESS BAGS. Send $15 \mathrm{c}$ (worth 20 c.) extra for a new estra heavy seamless bag, in which}

\section{Express or Freight Charges always to be paid by purchaser.}

For Large Quantities, or price on an assortment, write for special prices.

I Guarantee Safe arrival of the seed at your station. Do not forget to remit for sacks.

REDUCED FREIGHT CHARGES. In the past it has been the general practice of much for hauling seed grain as for market grain At a recent meeting of the General Offlcial Classitication Committee, in New York City, of all railroads, the charges on seed grain were lowered all over the country, to that of ordinary market grain. So now it will cost about one half as much as heretofore to ship seed corn, wheat, oats, etc.

I advise my customers to have their seeds sent by freight. As it is much cheaper than by express. I can generally reach most points in Ohio, Tennessee and Kansas, in three to eight days, and in Indiana, Missouri and Kentucky, in three to six days. By freight from here. I cannot send to a station which has no freight agent, as the freight charges must be prepaid to such stations. In such cases I advise you to order me to send it to nearest station to you which has an agent. Please give me the name of your nearest Railroad. Also how far, and what direction you are from the nearest of the cities named in the "freight rates." I guarantee safe arrival of the seeds at your station.

MV SELECTION Many of my customers send me $\$ 5,810, \$ 20$, up to $\$ 50$, and request me to send IISELEC them the worth of their money in corn, oats, or wheat, best suited to their soils, or to their localities. My knowledge of what varieties do best on particular soils or in particular localities, has been obtained by my personal visits to many localities, and by the report of my customers in all parts of the country. If you desire that I make selections for you, then please state in your order the character of your soil. Whether it is hard pan, sandy, red clay, brown, black, limestone, alkali, red shale, post oak, upland or lowland. And I will give you the most that I can for the cash you send, of the best varieties for your soil. them.

In filling orders we carefully label each kind, inside of the bags, so you wlll know them when you get

RAPID TRANSIT. I have rapid transit arrangements to many points. And with my system

The past spring I succeeded in reaching most Texas points in seven to twelve days. Most Louisiana points in six to ten days, and most Georgia points in seven to twelve days. It is always important to you to get your seed through quickly. You may rest assured that I will always use every means in my power to hurry your seeds through with the least possible delay in transit. I now put 2 or 3 Foster's Commercial tracers after each shipment. Delays are thereby quickly discovered, and the seeds pushed through with the least possible delay in transit. A well-known Georgia Seed Co., recently wrote me thus: "Please ship us the following additional order. Tracing in your usual energetic and effective manner."

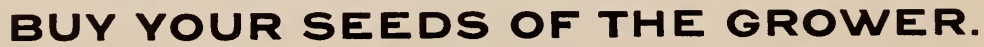

I acknowledge all orders, as soon as received. And notify my customers when I ship their seeds 


\section{SUFFERNS' ORDER SHEET}

Name

P. 0.

Co............... State.

Freight Station

Railroad

Send Seeds by

Amount Enclosed

$\oint$

Please state whether in Cash Stamps, Money Order or Draft.

Date.......189.

Plain letter paper can be used

for larger orders.
If we are sold out of any of the articles which your order on this sheet, are you willing for us to substitute anything of equal value and habit? Yes, or No

See bottom of page 2 , and center of page 5 .

IN MAKING YOUR ORDERS, PLEASE STATE THE PRICE

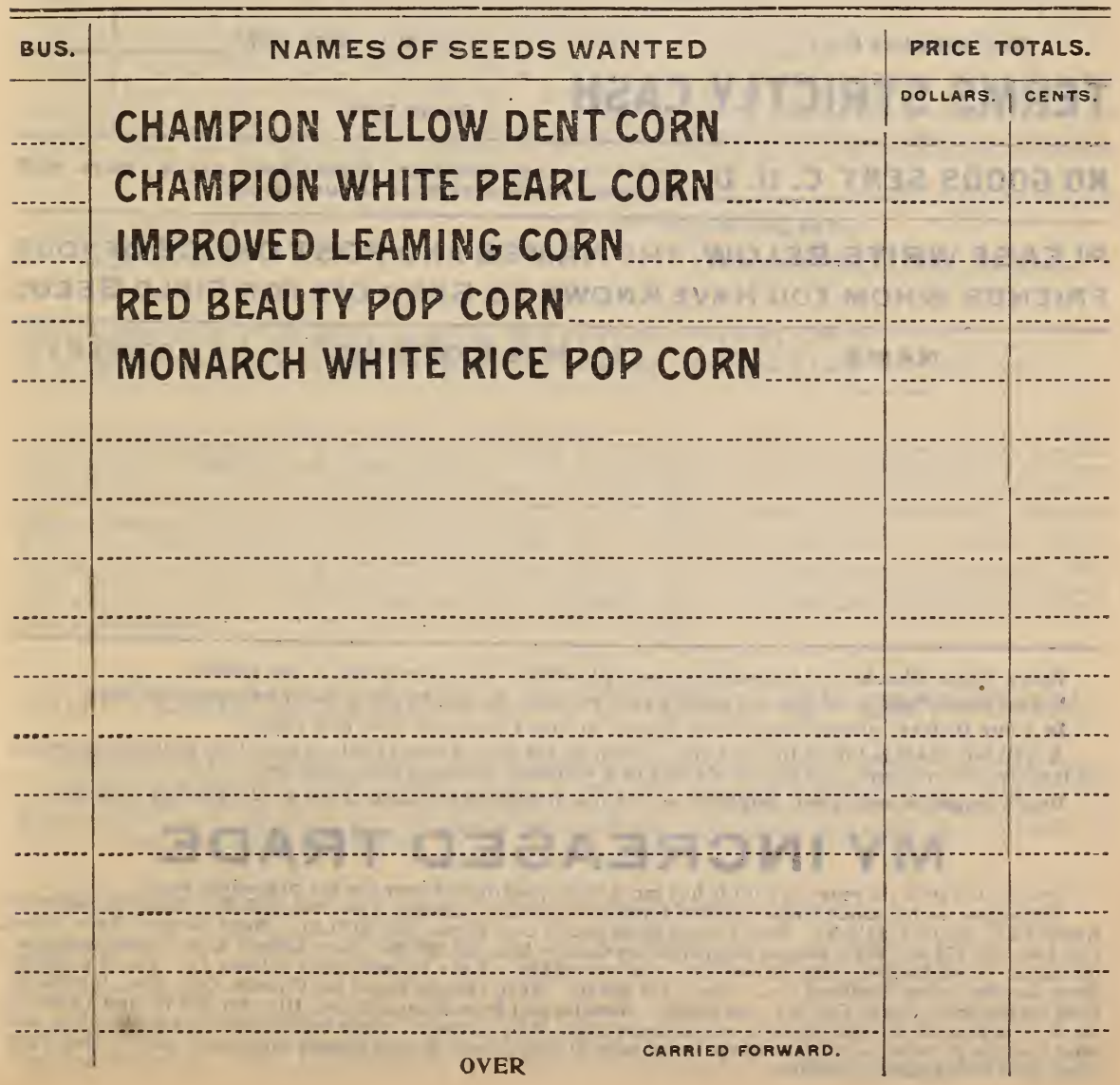




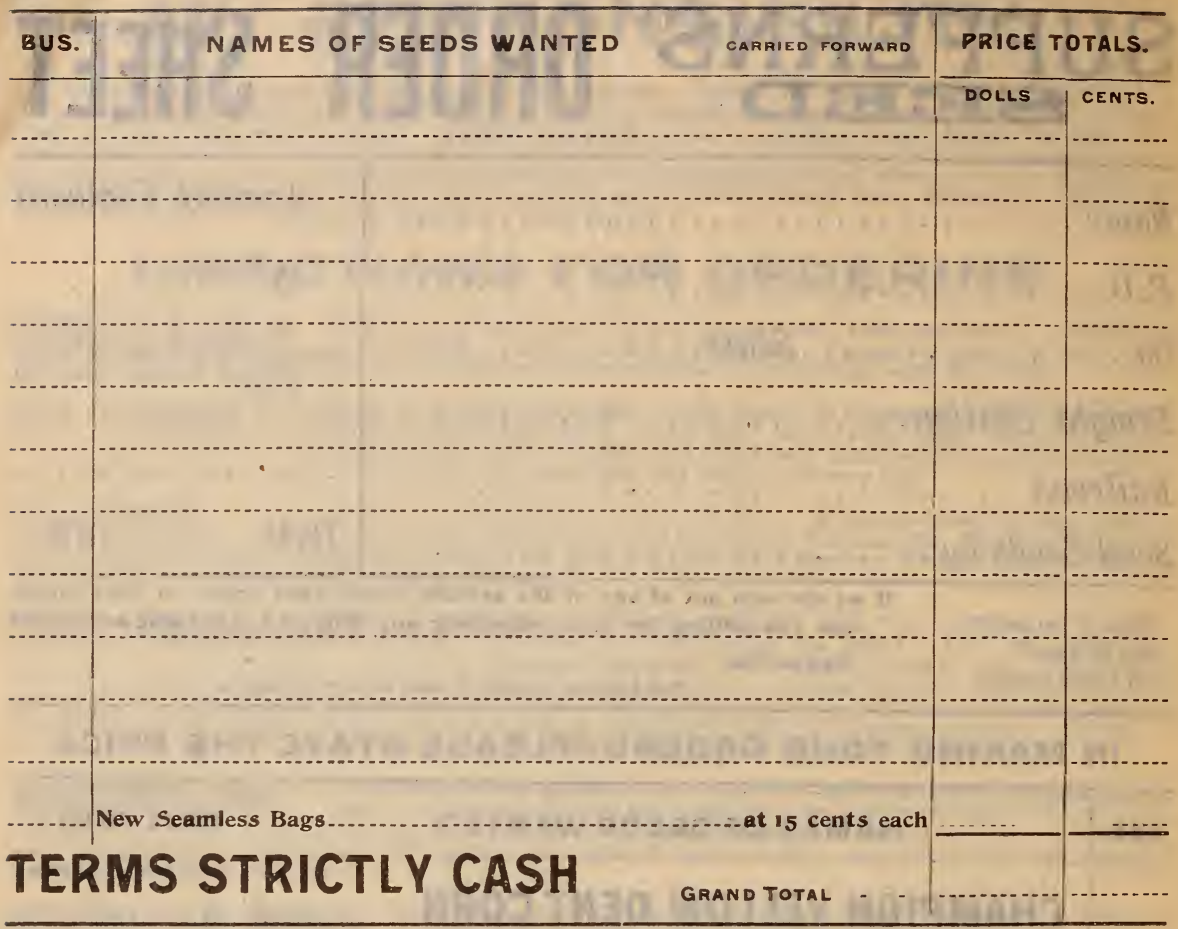

NO GOODS SENT C. O. D. Under any circumstances. Please don't ask it; extra work for us and needless expense to our patrons.

\section{PLEASE WRITE BELOW, THE NAMES AND POST OFFICE OF YOUR FRIENDS WHOM YOU HAVE KNOWN TO SEND OFF FOR FIELD SEEDS}

\begin{tabular}{c|c|c}
\hline NAME & POST OFFICE & STATE \\
\hline & POTE & \\
\hline
\end{tabular}

Extra Order Sheets will be mailed upon application. Buy your seeds of the grower.

I Guarantee Safe arrival of the seed at your station. Do not forget to remit for sacks, 15c each.

In Your Orders, please state second choice, in case I am out of your first choice.

A YOUNG MAN is full of life and vigor, when an old man is about ready to go to that bourne from which no traveler ever returns. So also of old and new varieties of wheat, oats, corn, etc.

Don't forget to ask your neighbor to join you in sending for some of our good varieties of seeds.

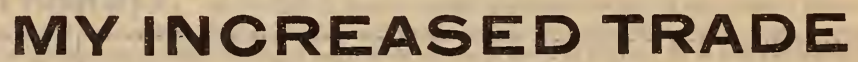

During the past six years, my trade has more than quadrupled over the six preceding years.

My largest order came from a club of farmers in Adams County, Ills., for $\$ 276.30$. Next largest from Neosho Co, Kansas, $\$ 117.50$. Next largest from Smith Co., Tenn., for $\$ 105.45$. Next largest from Posey Co.. Ind., for \$78.47. Next largest from Hickory County Mo., for \$74.35. Next largest from Tippecanoe Co., for $\$ 65.88$. Next largest from Brown Co., Ills., for $\$ 61.61$. Next largest from Adams Co., III., for $\$ 62.00$. Next largest from Bedford Co., Tenn., for $\$ 56.00$. Next largest from St. Charles Co., Mo., for $\$ 55.00$. Next largest from Grant Co., Ky., for $\$ 54.00$. Next largest from Hancock Co., Ills., for $\$ 53.75$, and 'so on. I am fully prepared this spring, for a much larger trade than I expect. Help form a club in your locality, and send me a large order, and make the price of seed 10 times over, in your largely increased yield. Don't put it off until next spring, order now. 


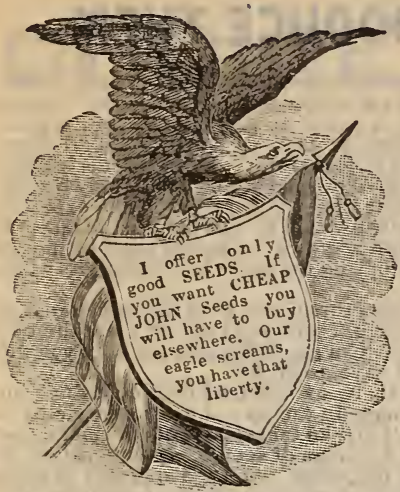

\section{SHALL I INTRODUCE MYSELF?}

To my old customers that is unnecessary. They have tried my seeds. And well know theirvalue. To you, I would say, with your permission, I desire a good, plain, common-sense talk with you, about seed grain. New varieties. Changing your seed. etc. It is not my purpose to bore you with a long-winded argument. But colsdense what I have to say, in the fewest words possible. And so ask your careful perusal of the following pages.

Many and varied are the claims to put forth for patronage. My hobby, as you know, is good seeds (not low prices). Good in every sense of the word. Grown from stock seed, which has been selected to a high standard. True to name and type. Yure and uniform. Not only good in form and appearance, but possessing inherent and invisible merit, that becomes distinctly visible in the product.

As you doubtless well know, to be permanently successful, it is necessary to use good seeds. What a world of meaning in these two words. What loads of disappointment implied by two words which express the reverse. What a delight to me after my customers have harvested their crops, to learn that my seeds in their hands have been money makers instead of money losers.

Some seedsmen yearly make a practice of introducing a host of so-called wonderful novelties. It is very amusing to note the laughable antics of certain seedsmen in indeavoring to create impressions that they have valuable seed novelties to otter. When as a matter of fact, they are recognized as cheats, introducing old varieties under new names, or so-called varieties produced in a year or two, in some wonderful manner. That a seedsman puts forward such unblushing lies about his novelties, is enough to condemn all his seeds.

But notwithstanding all this, every year is adding some valuable new varieties to the standard list. I am at work, breeding up a score of new varieties of field seeds. By a caretul, systematic selection. Aided by nature, this selection, extending through a series of years, keeping in view the ever-increasing ideal of excellence, is the only true way of the improvement of our seeds and plants.

I shall not introduce a new variety until it is worthy of introduction-in fact, until it is an Actual and Practical Improvement upon the standard varieties.

I have tried to give as near a perfect and an impartial description of my seeds as it is in my
To all would-be customers, I ask a trial order. I shall try hard to make your investments in my
seeds pay you the largest possible returns. It has ever been my constant aim to supply brother
farmers with new "tried and true" superior varieties of seeds, that will give satisfaction to the
buyer. An abundant patronage has rewarded my years of hard labor.
If you desire further information than I have given herein, do not hesitate to write me, for fear
of troubling me. It will not trouble me. It is my business, and a pleasure, to answer all letters
sent me. In conclusion I beg my readers to call my attention to any points in which I may have
failed to satisfy them. And can assure them that any suggestions made by them, any views pre-
sented by them, any questions asked by them will be gratefully considered. Trusting to be favored
with your correspondence, and early orders. I am,

\section{YOUR SECOND AND THIRD CHOICE Buy your seats of}

During the course of a large trade, it sometimes happens that the demand for some particular variety or varieties, is unexpectedly large, and soon exhausts my stock of it. While I will continue to have a good supply of other varieties until close of season. If it happens that I am sold out of part or all of what you order, it will be a great ttme saver to us both, and will prevent delay and disappointment if you will state in your order, (or make your next choice.)' if I may send a variety which I may consider as good, or about $z$ s good, or better, for your soil, (state what kind of soil you have), than what you order. And if the variety which I may send you, is lower priced than what you order, I will refund difference. If it is higher priced, will put it to you at the same price per bu. as the one you ordered. Or if you do not wish any but the kind you order, please state if I may order some good reliable Seed Co., to fill your order, with the same variety, at no extra cost to you. Or if you wish your money returned, I will do so. Be sure to instruct me in re= gard to the above.

\section{SUFFERN'S SEEDS ARE GROWN BY SUFFERN.}

FREIGHT RATES.-For the benefit of my customers, to save them time in writing ahout how much freight charges will be on a certain quantity of seed, I here quote you rates to 28 large cities. From the rate named to the city nearest you, you can draw an idea of about what the charges will be before you order. At distant points - 500 to 800 miles, the charges will be at least $50 \mathrm{c}$ on quantities of seed grain to amount of $100 \mathrm{lbs}$. or less. See bottom of page 2 .

Rates on seed grain in bags, per $100 \mathrm{lbs}$, at this date, from Voorhies, Ills., to-

Atchison, Kan.........32c Atlanta, Ga............. $42 \mathrm{c}$ Bowling Green, $\mathrm{Ky} . . .32 \mathrm{c}$ Buffalo, N. Y.........20c Chicago, Ill .......... líc Cincinnati, Ohio ....15c Council Bluffs, Ia... $.32 \mathrm{c}$
Cedar Rapids, Ia......24c Detroit, Mich..........12c East St. Louis. Ills ....17c Evansville, ind.......15c Indianapolis, Ind .......11c Kansıs City, Mo......... Lincoln, Neb..........36c
Louisville, Ky .........19c Milwaukee, Wis ..... Memphis, Tenn......3l'c Mobile, Ala...........37c Macon, Ga........... $44 \mathrm{c}$ Nashville, Tenn .......3ic Toronto, Canada.....20c New Orleans, La......2c Vicksburg, Miss......23c 
In the European countries. intensive cultivation is pursued far more intensely than in America. Here the system of farming (if system it can be called,) is cften conducted on happy-go-lucky methods. Consequently our cultivated lands as a whole, rarely produce scarcely half as much as they might. In the grain producing industry of this great country, the question constantly crowding upon the attention of all enterprising up to date farmers and land owners is: "How can I secure the largest yield.". Every farmer quickly admits that a big yield on a small acreage, is always more profitable, than a large acreage with only a moderate yield. It stands to reason that he is most prosperous who gets most from a given area. Then expenses do not increase in proportion to the yield. The added outlay comes when we go to increasing the area to get the increased yield desired. The bottom's out of farming in the old ways. Low prices can't be met by harder work, -you've got to change your methods. Raise double the crops on the same land, with less work. Can't be done? it is done!

The low prices warn us that we must raise larger crops on the same ground and with the same labor or our farming will not Pay. Nothing assists so much in growing the largest crops as to sow or plant the best seed. If 35 bushels of corn per acre will pay expenses of growing; if you can get 50 bushels per acre you will have 15 bushels per acre for profit, while if you only get 35 bushels you have no profit.

Progress is the leading characteristic of this age. The old is rapidly being replaced by the new and improved. It is truly wonderful to witness the progress that has been made in the way of increased yields in cereals, corn, and potatoes the past twenty years. It has become a well known fact to all good farmers, that our older varieties of cereals are continually running out. And that a change of seed is very important, in order to secure good crops. Those varieties known 100 years ago are forgotten. And those grown 25 years ago, are now nearly entirely out of cultivation. Whoever may have noticed, when the Fultz, Lancaster, Red Mediterranean, and Clauson Wheats were first introduced in the West, from the Eastern States, have seen, that in many instances their yields were almost double those of the older varieties then grown. After having produced several good crops, they too, have almost run out. And are fast going the same road that all the old varieties go, so it is with other grain.

In this age of new inventions, old machines, cereals, etc., are continually giving way to new and improved ones. In one short life, we can see the practical developments of human ingenuity. And become convinced, that we are not only subject to laws of gradual advancement, but that our forward strides in the Sciences, Agriculture, and Mechanics, have been great indeed. In this age of keen competition, the farmer who wishes to prosper, needs and gets the most improved farming implements; and by reading the best agricultural literature, he keeps in touch with the spirit of progress that pervades our farming communities. He is particular, also, in regard to the kind of seed he plants and the manner of planting it.

Indeed, the profit of grain production depends, to a great extent, on growing the right varieties. there being thousands of instances where eighty to one hundred bushels of the best qualicy of corn per acre might just as well be grown as thirty to forty bushels of a poorer quality if only the right varieties were grown. The old, run-out sorts which you have been growing, perhaps, for many years, should be dropped, and a stock of vigorous, new, thoroughbred varieties obtained. After you have tried them, you will see plainly that they are as much superior in every way to the old run out sor ts as are thoroughbred cattle to scrubs.

Thoroughbred cereals, especially the most highly bred of these, whose organic relations are so harmonious and plastic, and whose flexibility of organization has been so highly developed through the intervention of skillful breeders, are being continually transported from one part of the world to another, with the greatest success. Breeders have "moulded," by systematic mating and selection, an extraordinary inherent flexible and prepotent constitution which yields gracefully to changed conditions of life-soil, climate, altitude, etc. And changed conditions of life seem to be of the highest importance in favorably affecting the productive powers, by directly acting on this flexible organization. The greater or less force of organic flexibility determines how productive or profitable a plant will be under changed conditions of soil and clımate. If it is the possessor of a low organization, in which atavism or reversion is annually out-cropping, it will more or less suffer under changed conditions, as regards its productive capacity, owing to action of new chemical soil properties, proximity to bodies of water, mountain ranges, new insect depredators, etc.

Farmers desirous of changiug their seed should exercise the utmost care to procure only thoroughbred seed, to insure safe and sure increases in yields. The seed is parent of the plant, and bounds its possibilities. So critical an observer as the noted Dr. E. Lewis Sturtevent has given facts on which he rests a belief that the kind of seed used is capable of making as wide a difference in the crop as manured against unmanured land. And experienced farmers, who judiciously change their seed, have often noticed the same fact. To secure the best seed is of more importance to the farmer, and to the country generally, than it is to secure the best live stock. The plant precedes the animal, and its cost modifies the cost of animal products. It is an undisputed fact that the laws governing breeding are as potent in plant as in animal life, and respond as fully to the breeder's art. The successful plant breeder is never satisfied with what he has already attained. But, like the expert inventor of mechanical devices, he is continually striving for something better.

Hon. Isaac Morton said that "the product of one quart of a variety of wheat brought from North Carolina, in 1845, has benefitted the farmers of Preble county, Ohio, alone, more than $\$ 1000,000$ by the gain over what they would have had if they had continued to raise the old, run-out varieties."

A young man is full of life and vigor when an old man is about ready to go to that bourne from which no traveller ever returns. So also of old and new varieties of wheat, oats, corn, etc. Every old farmer can recall varieties that yielded abundantly in his younger days, but are out of cultivation now and their names almost forgotten. Of several varieties of corn that may be tried on any particular soil, one will yield almost double what some other will. The same is true of hardiness and other qualities. It pays big to get fresh seed from a different locality and soil (it seems almost a new being coming forth from the corpse of an old one), even if it be only the same old variety which you have been growing. A vigorous, hardy new variety will produce a good crop, in an unfavorable year, while a run-out tender variety seldom produces a satisfactory crop under most favorable conditions.

It will cost you only about twenty-five cents per acre to plant your whole crop with the vigorous, largeyielding new sorts of corn. And I can safely say that if you get the right sorts, your yield will be greatly increased and in many instances doubled. This has been the experience of the writer during many years of active farming. Let each farmer consider what an increased yield of one, two, five or ten bushels per acre on each acre of corn, wheat or oats he grows, will amount to and then hoze much money and time he can afford to spend to obtain these results. Owing to the superior yield that will be realized with my varieties of wheat, corn, oats, etc., it will pay to plant largely of them, to raise for the general market even at the price given.

In a letter just received from a gentleman in Central Missouri, he says: "I am satisfied that my yield has been increased at least one-third by changing my seed corn." Ask a German farmer what he thinks about changing seed, and he will almost invariably tell you that he believes in it, and believes in it strongly. At least, he was so brought up in Germany, in which country it is practised to a greater ,extent than any other country in the world. 


\section{CHOICE FIELD CORN.}

It has ever been my aim to raise and sell only the "tried and true" superior high bred kinds of field seeds Which are great practical improvements over the old run out kinds. Being as much superior to them as thoroughbred cattle is to scrubs. And which yield much larger quantities of much better quality than old kinds. Thus producing large actual gains, in dollars and cents, to those who raise them. I raise no corn that has an ear at every joint, and a quart of shelled corn in the tassel. No potatoes that cover the ground when dug. No overbearing watermelon-gooseberries, etc. Many of the so-called "Wonderful" new kinds of corn, I have found to be merely old well known kinds, introduced under new names, and sold under inflated extravagant claims. I have one such in mind, that was so introduced. And instead of being a benefit to purchasers, it has been really a damage to thousands of farmers, in all parts of the country. I do not catalogue it. As I want nothing to do with such sorts. The kinds I offer for sale, must first have been tried in all parts of the country, before I will think of offering them for sale. It has also been my greatest care to accurately describe all the seeds I offer for sale. Just as I know them, from having raised them on my own seed farm.

I make a SPECIALTY of SEED CORN. Having spent many years in improving and perfecting the corn plant. (I am still at it.) During these years, I have originated a number of new varieties of Corn. Every one of which have stood the fest of time and proven a great success in most parts of the country, have become recognized staples of the seed trade. One variety of which, particularly-Champion White Pearl, (to my positive knowledge there are several other kinds offered under its name.) I will venture to say has benefitted the farmers of the United States, to the extent of over 100 millions of dollars, in increased yields, and fine quality, over what they would have realized with old kinds. (See testimonials on last page of cover.) As there are few townships in which it has not been raised, during the fourteen years since I introduced it. For my Champion Yellow Dent Corn, I predict as great a success all over the U. S., as my C. W. Pearl Corn has achieved, I can say truly, that I have never raised or seen any other kind of yellow corn that combines so many good points as the Champion Yellow Dent does.

I have this year, as I always do, given all my varieties of Corn very careful sprouting tests. And find that there are VERY FEW grains that do not show a strong healthy sprout. The State Experiment Station at Urbana, Ill., has tested my Corn. Write them about anything you wish to know. They will answer you promptly.

I will further say: that I have much the largest, soundest, heaviest stock of Seed Corn to offer this year, that I have ever had.

It is pure and true to name, and nicely prepared for my customers. I send it shelled mostly. As nearly all of my customers want it shelled. As they have less freight charges to pay. Still I have some customers who want theirs in the ear. And I am always glad to send it in the ear if wanted so. But we do not shell nubbins. rotten ears, tips and all, as I regret to say, some has been, which I have at times received from certain seed firms. I only use about half (the best half) of the total product of an acre for seed. The other half I sell to grain merchants. Truly I find my best advertisements in my customers fields. I have plenty of almost every kind I offer, to fill all the orders which I may receive this year.

Below I quote the language of a large practical Missouri farmer: "Although I plant generally, a number of varieties of corn, in order to test their value, I select for my main crop, two kinds. First a large late kind for my early planting (if it does not rain so that I cannot plant early), and an 85 or 90 day corn for my late spring planting or to plant late on overflowed land, or to plant my whole crop with, in a spring like the present one. Generally this early corn does not yield as well as the large kinds, but if we have a severe July and August drouth, as we often do, the early corn will not grow to stalk so much, ear better, and outstrip the large late corn in yield. I always keep an early corn on my farm for replanting or late planting." Sensible is he, say I. I have planted 90 day corn on wheat stubble, on July the 5 th, and raised a good cropabout 45 bushels per acre. I always plant it twice as thick as large corn. As the stalks do not grow so large, but make their average sized ear.

TWO NEW CORNS.-I have 2 very valuable new varieties of corn, which after extensive tests in all parts of the country have proven to be real and valuable improvements over old varieties I have none of these two kinds for sale this spring. But expect to grow them in sufficiently large quantities the following year, to be able to supply a large demand for them.

To every person sending me an order for seed corn, accompanied by the cash, prior to March 20th, I will send a large package of either of these corns free, provided they request it when sending their order.

SAMPLES OF CORN. To intending purchasers, who will agree in thelp applications to show my samples, and this catalogue to their neighbors who want seed corn, and send me their addresses, I will gladly mail small samples of 2 to 6 kinds of seed corn, free.

MY PRICES. The seed dealer who imagines that prices alone, govern trade, is laboring under a great mistake. Prices alone, do govern trade with a certain class. A class who want everything at panic prices. And whom no amount of cutting in the world will satisfy.

I do not attempt to compete in price with growers who pay little or no attention to the quality and excellence of their stock seed. The roguing of their growing crops or the good preparation of seeds for their trade. My aim is not so much to offer "cut to the bone" prices, as to offer best stock for the money. In fixing my prices for the coming season, I have carefully considered everything relating thereto. And have placed my prices as low as high class seeds can be grown and sold at a profit. And low enough so corn growers everywhere can afford to order at least 10 bushels or more of seed. Especially when they consider a profit of $\$ 7$ to $\$ 12$ per acre in the increased yields and quality to be obtained by a judicious change of seed in addition to selling seed to neighbors, at good prices. Figure on it for yourselves. My profit per bushel is not large, but my profit is in the large number of bushels sold. I have made my prices on a basis of the market price of No. 2 corn, No. 2 wheat, etc. in Chicago, and St. Louis, on Jan. 20, '98. Whether the markets decline, or advance, after this date, I will in either case send you your money's worth.

If other reliable dealers quote any of the same varieties of seed lower than I do, then clip their prices from their catalogue (and give me their name) and mail with your order. Upon receipt of which, and the cash, I will fill your order. But otherwise, any correspondence looking to a reduction of my prices, will prove futile. But lower prices will be allowed on laıger quantities than 10 bushels.

Local dealers and others interested in having you buy at home constantly exaggerate the cost of shipping, to both your and our disadvantage. We will gladiy quote both freight and express rates to your town upon request. Freight and express rates have been much reduced.
"When a variety of seed is in the path of degeneracy, the best soil in the country, the most favor able season and the most thorough cultivation will fail to produce a satisfactory crop."

EDWARD TODD. 
A grand new Thoroughbred Corn. Tested and Proved. All and
more than claimed for it

Much encouraged by the success which the famous Champion White Pearl Corn (of which I am orjginator, ) has achieved throughout the land, I have, during the past 10 years, been breeding up towarcie a high ideal, a main crop superior yellow dent corn, suitable for general and extensive culture in the corn states.

First by a combination of crosses of several leading standard yellow sorts.

Subsequently by a continuous systematic selection, grasping, accumulating, and perpetuating, the superior merits of its parents, and the good points which nature continually evolves. Constantly roguing out the undesirable points.

After the 12th generation. its type and characteristics are thoroughly fixed. And I now believe my former ideal almost fully realized. For in all my extensive experience as a corn grower, I have never seen a variety that combined so many superior points necessary to the making up of a first-class main crop yellow dent corn. In fact it is what they call an "all rounder." Superior in every point. It now stands alone in my estimation, as the fittest and most superior general crop yellow dent corn for extensive field culture in all localities south of the latitude of the northern boundary of Illinois.

It will undoubtedly become a very popular early yellow "crop corn" throughout the Cotton States. Where it fully makes its ear in July, before the usual August drouths begin. Making good yields when the late native sorts make almost nothing. A letter now before me, just received from a gentleman in Central Texas, who made a test of it there, last year, fully demonstrates this. See what he says under heading of testimonials, on 4th cover page. While critical tests throughout the corn states, prove that it is all, and more, than I claim for it. In my own locality, where it is the crowned King of yellow corn, it is grown almost to the exclusion of all other yellow sorts, for miles in every direction. And anything to find such general favor at home, must possess great merit. I do not claim for it, magical wonderful yields. But I do claim it to be a remarkably uniform large yielding sure crop sort. Eighty to 100 bushels per acre over large fields, with only ordinary cultivation is a common occurrence. And high average yields for a series of years, are what fatten the farmers "pocket books." Then it rarely fails to produce paying crops even in the most unfavorable seasons. Very diligent selection has produced a profuse growth of pollen in the tassel, and an abundance of silk on the ear. And the simultaneous appearance of these on the same stalk, and on all the individual stalks, combine to produce a very perfect fertilization. To this fact alone do I attribute its high average yields, and uniformly superior quality of grain.

As the originator of this corn, I desire that it make its way into general public favor solely by a reasonable extolling of its merits. And not meteoric like, to be sold under inflated extravagant claims.

It can be depended upon, when planted by June 15th, to make good corn by Sept. 15th. When planted early, matures in 100 days. The grain, owing to an unusually large solid oily germ, has peculiarly high germinating powers, seldom germinating less than 100 per cent. Truly a most valuable feature.

It makes a rapid strong healthy spring growth. A short thick strong jointed stalk, with a profuse growth of air roots which hold it firm against storms. It has very long tap roots, which reach deep down after moisture during dry weather. A very profuse growth of pollen and silk, producing very long heavy well filled ears, which grow upon very short small shanks, close to and low upon the stalk, and contains 16 very straight compact rows of rich golden colored starchy oily grain of a uniformly high grade, and which makes a No. 1 feeding and milling corn. It has a very small red cob. Get a start of it now. It will make extra dollars for you in future years.

MY PRICES.-By Freight or Express.-Peck $60 \mathrm{c}, 1 / 2$ bus. $\$ 1.00$, one bus. $\$ 1.75,2$ bus. $\$ 3.25,5$ bus. $\$ 7.75,10$ bus. $\$ 15.50$. Postpaid prices $-11 \mathrm{~b} 40 \mathrm{c}, 3 \mathrm{lbs} \$ 1.00$.

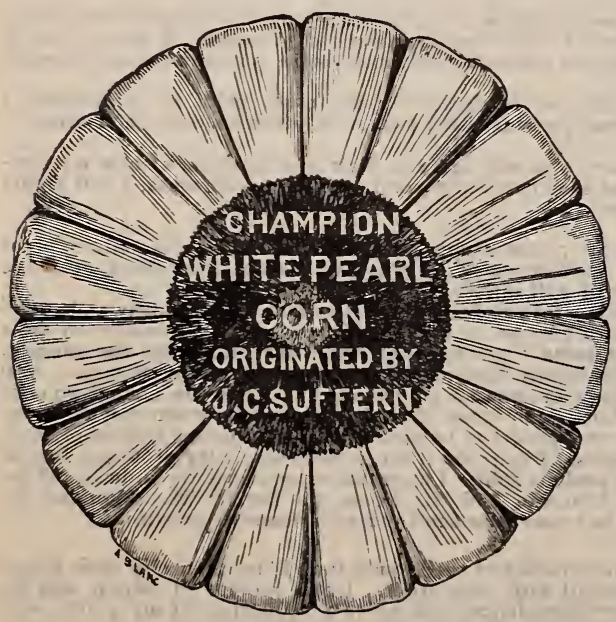

ENGRAVED FROM A PHOTOGRAPH.
A sample ear put in each bushel of shelled corn. I recommend C. Y. Dent for all points south of Northern Ohio, South Central Mich., Northern Ills., North Central Iowa, and North Central Neb.

I have plenty of it to fill all orders.

SEE ILLUSTRATION of C. Y. Dent on outside page of cover. It is an exact representation of an ear which I husked on Sept. 14, 1894.

\section{Champion White Pearl.}

The popular Dent Corn, which stands to-day without a peer. The most complete success of the age. Confirmations crowd in from the east, the west, the north, the south. The handsomest white dent corn ever seen. Very productive, ripens in 90 to 100 days. Brought to its present high standard by 21 years of continuous, systematic selection.

In the introduction and dissemination of this corn, my former claims (14 years ago), have been abundantly borne out. Instead of sinking into oblivion in two or three years, as do many high blown sorts, it has solely on its own merits, grown into such general public favor, that to-day it is recognized and catalogued as the leading standard variety of thoroughbred pure white medium sized early white dent-corn. It did not sprout up in a year or two, but I have brought it to its present high standard by 21 years continuous accumulative selection. Each year placing it on a still higher plane of purity, vigor and perfection. So that to-day it is far ahead of 14 years ago. It scored the highest average yield at the Illinois Agricultural Experiment Station, Urbana, Ill.. during an extensive variety test, covering a period of 6 years, 1888 to 1893 inclusive. See bulietin 31, March, 1894. In 1893 it was far ahead of a number of
varieties, at the Oklahoma Experiment Station, Stillwater, Okla. See bulletin 10, for 1893 . In 1890 and varieties, at the Oklahoma Experiment Station, Stillwater, Okla. See bulletin 10, for 1893 . In 1890 and again in in 1892, it took first premium at the Iowa State Fair, and went to Columbian Exposition as the best
corn from Iowa. It has won first premium at Nebraska state fair for the period of 6 years. Indeed, its 
superiority is so well known, and so widespread, that nothing further need be said in its favor here. I recommend it for all localities south of Detroit, Mich., Southern Wisconsin, Northern Iowa, and Northern Nebraska.

True merit alone, has won bright laurels for this corn. It being now recognized as the leading standard sort of pure white, very long grained very starchy floury best milling early general crop corn of the highest possible quality. Very small white cob. Short thick robust deeply rooting stalk, with ear very low upon it. Thus standing severe storms and droughts well. Very uniform in fertilization and maturity. Maturing in 100 days. An immensely high average yielder all over the corn belt, and in the Cotton States. A Loeuty, ad in escry bespest in wrst-class white sure cropping corn.

At ray prices it will cost you only about $25 \mathrm{c}$. per acre to plant your whole crop with the C. W. Pearl Corn. And which is only about half of what oats seeding costs. Then why plant poor run out corn. (In a letter just received from an old customer of mine-Mr. J. B. Piersol, of Rockwell P. O. in Northern Iowa, he says-"The corn I got from you last spring, yielded me 62 bushels of corn per acre. Which was better than our corn from other seed-see testimonials - I attribute the extra yield to the change of seed. Which I have found to be of great advantage.") I can assure you that one acre of it will yield more than enough extra for you, to pay for 3 to 5 bags of my seed.

MY PRICES-By mail postpaid, ib. 30c. 3 tbs. 75c. By express or freight, Peck 45c. 1/2 bus. 75c. One bus. $\$ 1.40 .2$ bus. $\$ 2.555$ bus. $\$ 6.00$. 10 bus. $\$ 11.50$. New extra heavy seamless bags in which to ship each 2 bus. or less of seed corn you order, I charge $15 \mathrm{c}$. extra for. Do not fail to send their cost when you order. Write for my special prices on larger quantities than 10 bus. I ship by freight mostly, and trace well to hurry seed through.

SEE ILLUSTRATION of C. Y. Dent on outside page of cover. It is an exact representation of an ear which I husked on September 14, 1894. Being made by an engraver - Mr. A. Blanc, 314 N. 11th st.

\section{IMPROVED LEAMING CORN (Medium Yellow Dent.)}

This popular and distinct variety of yellow dent corn, certainly has beyond question, reached the grandest success of any yellow dent corn that has ever been brought before the farming public. It was brought to its present high state of perfection by 30 years continuous systematic selection. By its originator-J. S. Leaming, of Clinton Co., Ohio. This noted and much praised corn, was first brcught to popular public notice at the World's Exposition, Paris, France, in 1873, where it received the highest award for a yellow field corn. Since then it has been tested all over the United States and has given fine satisfaction. This is a medium-sized, golden yellow corn. The stalks grow to a medium height, not large, but thick, has but few suckers, and often produce two fine ears, which in the true Leaming, are low upon the stalk. The grain is long, narrow, and thick, and sets very close together in the rows. The cob is medium-sized and very red. This corn husks and shells very easily, and weighs 60 to 62 pounds per measured bushel, and matures in 90 to 100 days. Don't fail to try this Grand Corn. My seed was grown from seed obtained direct from the originator, and is pure. I recommend this corn for all localities South of Chicago, Ill., Toledo, Ohio, and Omaha, Neb. Prices: By mail postpaid, Lb. 25c. 3 tbs. 70c. By express or freight, Peck 40c. 1/2 bus. 70c. One bus. $\$ 1.35$. 2 bus. $\$ 2.45$. 5 bus. $\$ 5.75$. 10 bus. $\$ 11.00$. Write for my special prices on larger quantities than 10 bus. See freight rates, on page 5.

\section{HICKORY KING CORN (rredium White Dent.)}

This new white field corn has the largest grains, with the smallest cob of any white corn ever introduced. So large are the grains, and so extremely small the cob that on an ear broken in half a single grain will almost completely cover the cob. No other variety of field corn that I have ever seen will do this. Of strong, vigorous growth, the stalks take a firm hold in the ground and stand upright, resisting the severest storms, the stalks generally bear two ears, and occasionally three. It yields splendid crops on light soil, and is undoubtedly a more productive white corn to bulk of ears than any other variety. It makes a splendid quality of corn meal and is "just the thing" for cattle feeding. As it is almost all corn, with but very little cob. I recommend it for all localities south of Central Ohio, Central Illinois, and Northern Kansas. It matures in 115 to 125 days. PRICES: Same as for Improved Leaming Corn.

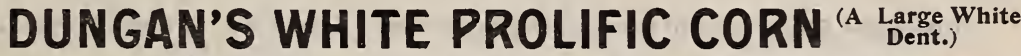

This large white dent corn was introduced by Mr. S. W. Dungan, of Indiana. It has a large amount of foliage, and stands drouth better than some kinds. It is much like my C. W. Pearl Corn, and much the same description will answer for it, except that it is not so early. My stock was grown from seed grown from headquarters stock. And is pure and true. I recommend it for about same latitude north as Golden Beauty. PRICES: Same as for Improved Leaming Corn.

\section{BLOUNT'S WHITE PROLIFIC CORN $\begin{gathered}\text { Or Mammeth } \\ \text { Ensilage.) }\end{gathered}$}

This excellent variety of fodder corn, was originated by O. E. Blount, now of Colorado Agric, Experiment Station. It has produced over 40 tons of green fodder per acre. And in 1889, on my seed farm, it produced 118 bushels of grain per acre. The ears are long, slender, and average $\mathscr{Z}$ per stalk. I have seen 8 ears of it on one stalk. It matures in about 125 days. I recommend it for all localities south of Central Ohio, Central Illinois, and Northern Kansas, for grain and north indefinitely for fonder.

\section{CUBAN GIANT CORN (or White cob Ensilage.)}

This is much similar to the well known St. Charles White. But has a white cob, longer and slimmer ear, and matures about 15 days earlier. It is a large fodder yielder, and a very heavy grain yielder. In fact an all round good white dent corn, and does extra well in the Cotton states. PRICES: Same as for Improved Leaming Corn.



A large growing red cobbed white dent corn, with a profuse growth of foliage. Originated and much esteemed in the vicinity of St. Louis, Mo., as a general crop sort. And quite popular in the north as an Ensilage corn. I have nice pure seed. It will mature wherever Golden Beauty Corn will. PRICES: Same as for Improved Leaming Corn. 
I have never seen a more handsome yellow dent corn than this. It has nicely shaped ears, well filled out, and containing about 16 rows of golcien yellow-colored, long, broad grains. It is a very heavy yielder. And the fact that it has a medium soft grain, makes it valuable for stock feeding. I highly recommend this corn, for all points south of Columbus, O., Springfield, Ill., or Atchison, Kan. The stalk is strong, and medium tall. It matures in 110 days. PRICES: Same as for Improved Leaming.

\section{EARLY BUTLER CORN 100 Day Yellow}

This new Early Dent Corn was first sent out three years ago and has grown in popularity very fast. It has the largest ear of any of the first very early dent corns. Also the deepest grain and the most rows on the cob. It grows strong, rank and quick, and will out sell any early variety in cultivation. On trial one bushel of seventy pounds shelled sixty-four and one-half pounds, leaving only five and one-half pounds of cobs. Every farmer should give this fine yellow corn a trial. PRICES: Same as for Champion White Pearl Corn. It will do well wherever the Pride of the North will, but is a larger corn.

Don't forget to ask your neighbor to join you in sending for some of our good varieties of corn.

\section{WHITE CAP YELLOW DENT CORN}

This corn comes from a large grower of all kinds of seed corn, and is a corn of great merit. It grows large ears and matures early. The ear grows almost as large as Leaming and is from seven to ten days earlier, and on poor, thin soil will yield thirty per cent more corn. It grows strong, rank and quick, and, it is claimed, will produce more corn on poor, thin soils than any other kind now in cultivation. It will be appreciated by those living in droughty sections and by those farmers who have poor, thin soil, while on strong, rich soil it has no superior. The tip end of the grains are white, the inside yellow, making it a beautiful color. Large growers in the corn belt, as well as those out of it, will be pleased with this corn. Price: Same as for Champion White Pearl Corn.

\section{PRIDE OF THE NORTH CORN.}

This is one of the earliês $t$ dent corns in cultivation. When planted in Illinois, on the 4 th of July, it has fully matured before frost; it can be planted twice as thick in the hill as large corn, and at the same time bear a full sized ear; this is a small sized dent corn and matures in 87 days. The stalk is short and thick, and stands storms well. Ear is from 7 to 10 inches in length, and 1\%/8 inches in diameter; the grain is of a deep yellow color, is long, thick and narrow, and of a very oily nature; the cob is very small and red. I highly recommend it for all localities south of Central Mich., Central Minn., and Central Dak. See testimonials on page 16. PRICES: Same as for Champion White Peari Corn.

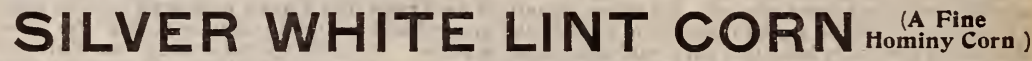

This popular thorough-bred large white flint corn, originated in New York. Its ears often grow 15 inches long, and produce 50 to 60 bushels per acre. It is a very fine hominy corn. It is also fine for early fall hog feed. It matures in about 85 days. Pfices: Same as for C. W. Pearl Corn.

I Guarantee Safe arrival of the seed at your station. Do not fail to remit for sacks, $15 \mathrm{c} \mathrm{each.}$

In your orders please state $2 d$ choice, in case I am out of your 1 st choice.

\section{IOWA GOLD MINE CORN (An Early Yellow $_{\substack{\text { Dent. } \\ \text { Yew }}}$}

A very popular yellow dent corn originated in Central Iowa. It has a very long yellow grain, and very small red cob. By a careful test, 400 measured bushels of its ears shelled out 456 bus. It matures in about 9: days. And gives good satisfaction as far north as northern Iowa. My seed was grown from direct headquarters stock. Price: Same as for Champion White Pearl Corn.

\section{IOWA SILVER MINE CORN.}

A new early white dent corn introduced from Iowa last spring. It is a 95 day good yielding, pure white corn. From records in various parts of the corn belt, it has given good satisfaction. My stock seed was purchased from the introducers.

PRICES: Same as for Champion White Pearl.

I desire all my readers to write me their experience-their opinions on novelties. How they manage. What new ideas they have. What fine varieties of wheat, oats, corn, or potatoes have you this year? Which kinds have done the best for you? Where did you get your start of them.

Mr. Henry Brown, Crab Orchard, P. O. in N. W, Missouri, says: "The C. W. Pearl corn I got from you, I planted last and gathered first. It yielded 60 bushels per acre. It is the purest, whitest and best bread corn I ever saw ; neighbors think very highly of it.

Mr. J. A. Trưs, Lawn Ridge, Marshall Co., Ill., says : "I had good success with the seed oats which i bought from you. They yielded 16 bushels per acre more than other oats I raised on same kind of ground and same kind of cultivation. 


\section{CHOICE SWEET CORN.}

Stowell's Evergreen. A late variety of excellent quality, remaining longer in green state than any other kinds.

Gold Coin. This is 10 days earlier than stowell's Evergreen, similar in appearance except kernels are yellow; very ploductive, two or three ears on a stalk; very sweet.

Egyptian. Ear's large. Ripening late. Sweet; prolific; demands a high price in market

Country Gentleman. This distinct, medium-late, popular variety, has the smallest cob, and deepest gram of any known variety. The kernel is white, tender and juicy. It is very productive.

None Such. A new second early sort, of great merit. The orioinator in northern Ohio) offers $\$ 100$, for its equal in quality It has a pink cob and white grain. Good sized ears, and is a big yielder. I have the genuine seed.

PRICES: Postpaid, packet 5c. qt. 30c. By Express or fast freiglit Peck $\$ 1.00$. Bush. $\$ 3.00$, for all of above kinds of sweet corn.

\section{MY POP CORN SEED.}

The growing of pop corn, the last few years has become quite an industry And the country has been greatly in need of pure uniform varieties. As you will
note below, 1 offer seed of popular varieties. I take extra care to grow very pure seed, and to prepare it
nicely-shelled and re-cleaned. I can also furnish selected ears at same prices as the shelled corn. The past $\bullet$ year my trade on pop corn seed, more than quadrupled $ᄃ$ over the previous year

\section{NEW RED BEAUTY.}

This raluable new rice pop corn was originated by an expert pop corn grower of fllinois. who while rogueing a tield of snow Ball pop corn, in the summer of 1888, discovered a sport of a remarkably peculiar style. Since, by isolation and careful accumulative selection 5 of he has secured a variety, which for rare beauty, extreme earliness, great productiveness, crispness, tenderness, great depth of grain, and smallness of cob cannot be equaled. 50 bushels per acre being a common so
yield. It pops splendidly 4 months from time it is planted. In every respect a first-class family pop corn.

PRICES for Red Beauty; postpaid, packet, 10c: one to $40 \mathrm{c}$. By express or freignt, Peck $\$ 2.00$. One bushel $(60$ tos. shellèd) $\$ 7.00$

\section{MONARCH WHITE RICE.}

After 10 years very careful systematic selection I have succeeded in breeding up a variety of pop corn which combines the most desirable qualities, viz: great $a$ 工

productiveness, early maturity, tenderness, sweetness, beautiful snow white color, greatest bulk after being parched, uniformity of type, and the fact that its thorn at outer end of grain, turns toward the cob, forming a hook, which does not prick the hands while husking. Thus avoiding the common objection to growing rice pop corn. This variety parches well by December 1 st, of the year in which it is grown. And in time for the holiday trade. Whereas most varieties must be carried over into the next summer, before they are suitable to the parching trade. To which the Monarch $\boldsymbol{u}$ hite Rice sells for a higher price than any other sort. It bears from 2 to 6 ears per stalk, weighs $36 \mathrm{tbs}$. per bushel of ears when dry, and produces 1500 to 2000 tos. per acre. Like C. W. P. Corn, this practical, early pop corn is steadily growing into general favor. 1t has "come to stay." If you miss it, you will miss a good thing.

PRICES: Postpaid, packet 10c. Lb. 35c. 3 tos. 90c. By Express or fast freight, Peck $\$ 1.75$ One bus. (60 tos. shelled) $\$ 6.00$.

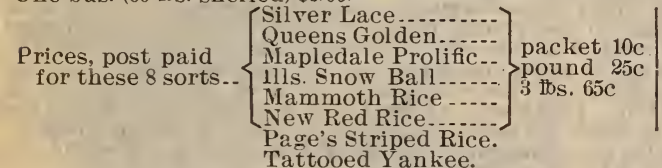

By Express $\{$ Peck, shelled, $\ldots \ldots \ldots$

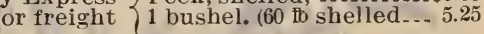

\section{CHICE SEED OATS.}

White Bonanza Oats.-This is the variety that was awarded the American Agriculturists' special $\$ 500$ prize, for a yield in Orleans Co. New York, of over 133 bus. per acre, in 1889. It is an extra nice, heavy wlite oats. I highly recommend it.

Clydesdale or Race Horse Oats - A very early variety, weighing 45 tos. and over per measured bushel. Well-cleaned samples have weighed over 50 ths The straw is straight and stiff, holding up well its immense branching heads, 20 inches in length, with rather short plump grains. It is reported as having yielded from 90 to 100 bushels per acre.

LINCOLN OATS.-This valuable new white oats, first introduced in 1893, has been largely sold in all sections of the country, and has given fine satisfaction. My seed was grown from stock obtained direct from the introducers last spring.

MEXICAN GRAY OATS.-A new extra.early gray oats, particularly suited to the south and west. As it is so early that it matures its grain before hot winds or rust set in. Straw short and thick. A big yielder every where almost.

TEXAS RED RUST PROOF OATS.-At the Illinois Experiment Station, Urbana, Ills., this new red oats has proved to be the largest yielder of many varieties there. It does well on black soils throughont the north. It is very early.

My Prices.-For any of the above named kinds of oats are as follows: Postpaid, 1-lb. 25c 3-lbs 60c. By express or fast freight, Peck $30 \mathrm{c}$. $1 / 2$-bus. $50 \mathrm{c}$. One bus. $85 \mathrm{c}, 2$ bus. $\$ 1.60$. 5 bus, $\$ 3.50$. 10 bus. $\$ 6.50$. 
Potatoes will be shipped in favorable weather only. We commence shipping Potatoes about the first week in March. If you want your Potatoes shipped before March, please state so in your order. But we will not be responsible for damage they may sustain during transit from either cold or heat.

\section{EARLY VARIETIES.}

Early Six Weeks Market.-Ready for market in 6 weeks, matures in 75 days. It grows me dium to large. Light flesh colored. Smooth. Eyes even with surface. They are so early that potato bugs have but little chance at them. They are solid and mealy, and are not excelled as a table potato.

The Crown Jewel.-New; a self-seedling of the Early Ohio; is about a week earlier than the Early Rose or Early Ohio, and will yield nearly double of either; quality the best. The Crown Jewel is a strikingly beautiful potato; shape oblong, size large, skin white and smooth, flesh pure white and floury, in keeping qualities is equal to the best.

Barly Beauty of Hebron.-Extra Early. Resembles Early Rose, but matures a week earlier; grows very rapidly, which helps it withstand the attacks of insects. Skin smooth, white, sometimes pinkish tinted, but becomes white in Winter; tubers of good size, round, flat oblong in form; flesh white, solid and of delicate flavor.

\section{LATE POTATOES.}

Burpee's Superior.-Long, round or slightly flattened, skin pure white, netted; eyes plenty, rather small and even with the surface, giving it a very smooth, handsome appearance, size medium to large, vines large and vigorous, This is far ahead of Star and Burbank in all desirable qualities.

Rural New Yorker No. 2.-This new potato, introdnced in 1889, is proving to be one of superior excellence. Oblong, round or oval; skin pure white, netted; eyes few and even with the surface; size large to very large, vines thrifty and strong. In productiveness and quality it is scarcely equaled. Remarkably vigorous, very productive.

EARLY PURITAN. This variety was originated by Mr. Coy of New York state, who originated the Beauty of Hebron and over a dozen other varieties. The skin and flesh are very white. It cooks dry and floury. Its greatest value is in productuveness. It yields nearly double that of the Early Rose; is early as Early Rose, and wonderfully dry when but half grown. The vines are vigorous and upright.

NEW QUEEN. Whether on poor thin soil or rich bottom land this potato has done surprisingly well. Very early, extra quality, wonderfully productive, size large, color white, shape long, smooth and clean. A fancy market variety.

PRICES for all above named varieties of potatoes, are as follows-By Express or Fast Freight, One bushel, $\$ 1.50$. One barrel $23 / 4$ bushels $\$ 3.75$. Prices subject to Changes ot the Market.

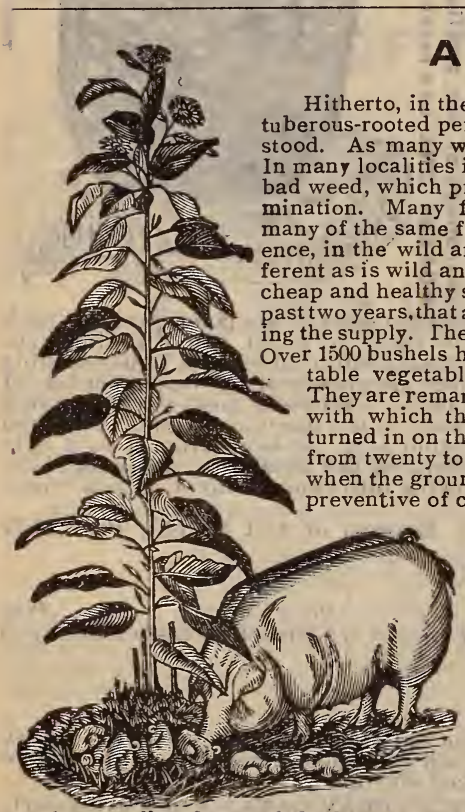

\section{ARTICHOKE SPECIAL.}

Hitherto, in the United States, the growing of the domesticated sorts of this

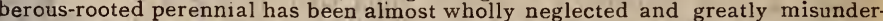
As many well informed men know, there are Artichokes, and Artichokes. In many localities in North Ameriea the wild Artichoke is a native. It is merely a weed, which produces very few and inferior tubers-a pest, difficult of exterMany farmers who have seen it growing, fully understand that, But many of the same farmers do not understand that there is a difference, a vast differce, in the wild and domesticated (tame) sorts. While, as a fact, they are as difand "tame" rye. The great value of the domesticated sorts as a cheap and healthy stock food, has been so thoroughly aired in the press, during the immense demand has been created, in many instances far exceed-

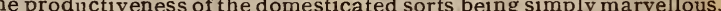
s having been dug from one acre. They are sometimes used as a table vegetable when pickled, but their greatest value is for feeding stock. 作 ith which they can be grown. They rieed not be dug; the hogs should be thirty hogs in fine condtiion from October until April, except when the ground is frozen too hard for them to root. They are also said to be a cholera and other hog diseases; and they are also highly recommended for milch cows, increasing the yield of milk and at the same time improving their condition. 5 bushels of seed for one acre. They should be cut the same as potatoes, one eye to a cut being sufficient, planted in April or May, in rows three feet apart and two feet in the rows, and covered about two inches deep. The land can be easily cleaned of them by plowing under when tops are 1 foot high. I feed my horses and cows on them every spring and fall. They always eat the tubers in preference to oats. They are as good, or better for horses, than is condition powders. Making them shed nicely, and look sleek and fat. I would not think of farming without them.

MAMMOTH WHITE FRENCH. This fine variety was recently brought from France. Where it is largely used for human food, as well as for stock feed. It grows larger and nearer the surface, and is better for pickling than other sorts.

WHITE JERUSALEM. The peculiarity of this sort is its predominance of pinkish eyes. It also grows more in clusters than other sorts. It makes enormous yields. One acre being worth about 10 acres of cor $n$, for hogs.

RED JERUSALEM. This is a sport from the White Jerusalem, very similar except in color, which is bright red. But it is more dwarf, and its tubers grow larger. Hogs root out and devour it greedily.

RRICES: For any of these three kinds of artichokes are: Postpaid, Lb. 25c. By express or fast freight, Peck 40c. $1 / 2$-bu. 75c. One bus. $\$ 1.00$. 5-bus. $\$ 4.25$. I ship in sacks.

When Letters are mailed in Ohio, Ind., Mo. and Kansas, to-day, fast mail generally deliver them to me on to-morrow. Get your neighbors to order with you.

I desire all my readers to write me their experience-their opinions on novelties. How they manage. What new ideas they have. What fine varieties of wheat, oats, corn, or potatoes have you this year? Which kinds have done the best for you? Where did you get your start of them? 


\section{White Beauty Sunflower.}

For elght years I have been breeding towards a pure white Mammoth Sunflower. A very difficult, patient undertaking it has been. But now I can exclaim: EUREKA! I have it at last. A sun= flower with Snow White Seeds. It's a novelty indeed. A novelty in 1,000. And is sure to meet with a large and enduring sale.

After years of careful selection I am rewarded with a purely bred Mammoth Single-head Sunflower with pure snow white seeds, which on account of the deficiency of strong coloring matter in the outer covering of their kernels, are much superior to the darker sorts for stock and poultry food. It also produces a much milder, better flavored oil.

This strikingly distinct new sort, is not only the most beautiful, the most vigorous, the most valuable for stock and poultry feeding, and for oil production, but owing to the fact that all its powers are expended in producing one mammoth head, it is simply a marvel for productiveness. Out-yielding the old sorts almost two to one. $3000 \mathrm{Dbs}$. per acre being no unusual yield. I feel much gratified in being able to offer it to the trade. Being confident hat it will take the lead in Sunflower production.

Price.-Packet $10 \mathrm{cts}$., $1 / 2-1 \mathrm{~b} .35 \mathrm{cts}$.; $1 \mathrm{tb} 65 \mathrm{cts}$.; 2 tbs. $\$ 1.00$, postpaid.

Money Insured. - I guarantee to hold myself responsible for the safe arrival of all remittances, when sent according 0 my instructions.

Mammoth Russian Sunflower.-A standard well known fray seeded variety. Large packet $10 \mathrm{c}$; $1 \mathrm{lb}$. $25 \mathrm{c}$ postpaid.

New customers are requested to investigate my standing.

Errors will occur in spite of us-no one is infallible. You will find me ready to do the right thing in case of an error.

Freight Rates are as low, and in many cases lower, to points in Ohio, Tenn.. and distant states, than to points in Illinois. See table of rates on page 5.

\section{MY 1899 CATALOGUE}

will be ready about Feb. 1, 1899. If from any cause you fail to receive a copy of it before March 1, 1899 you can order from this catalogue. As prices wil be about the same. In every case, we will send your money's worth, or abide by instructions you give when you send your order. It is always my aim to make your dealings with me, pay you. For only by so doing can I expect your continued patronage, and that of your friends.

SWEET POTATO PUMPKIN. - This is the best variety for making pies and custards, that I ever saw. When baked it is much superior to sweet potatoes. Flesh creamy white, very fine grained, dry and brittle. It grows to medium size, is very prolific, and keeps well until late in the spring. PRICES-Large packet $10 \mathrm{c}$. $1 / 4-\mathrm{tb} .45 \mathrm{c}$. Lb. $\$ 1.40$ postpaid.

WEED SEEDS. - In nothing about my business am I more careful, than in keeping all dangerous weed seeds, such as Canada thistle, wheat thief. cockle, etc., out of my seed grain. I have at times received from eastern seedsmen, seed grain that was full of these noxious weed seeds. Seeds which I each year plant on my own farm, from which I grow my large seed crops, .are grown from very carefully hand-picked seed. All noxious weeds. impure grain, etc., being picked out. I let no seed grain leave my establishment which contain these foul weed seeds, if I know it. Be careful of whom you purchase.

SUBSTITUTING.-Orders received before $\mathrm{Mch}$ 20 , will be filled without substituting, unless permission is given to substitute. After March 20, as there will be no time for correspondence, we reserve the right to fill any order, if necessary, with other varieties equally good and of the same season, unless the order distinctly states "No Substitution Allowed,"

\section{MISCELLANEOUS FARM SEEDS.}

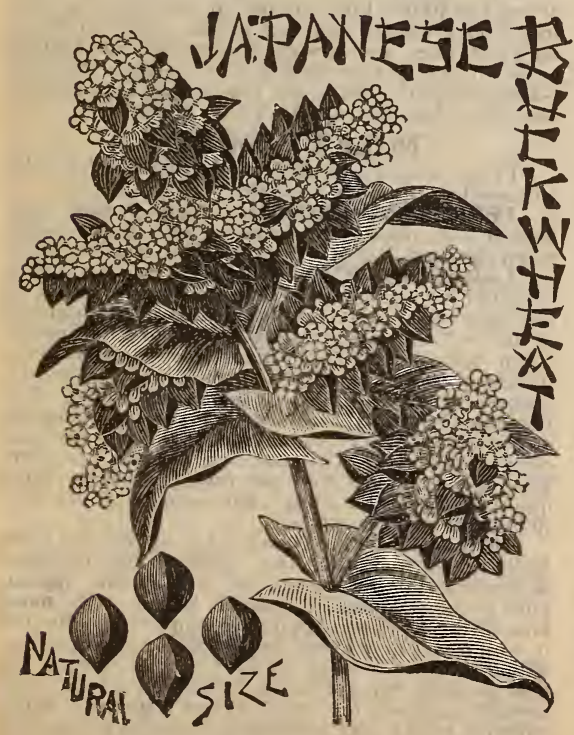

WHIP=POOR=WILL. Pk., 60c., bu., $\$ 2.00$.

\section{Japanese Buckwheat.}

This extremely valuable variety, was imported from Japan in 1883. It is a novelty out of 1,000 , that is up to. and ahead of all that is claimed for it. The old varieties now, may well be laid in the shade. Especially the old black kind, which on account of its being blasted by the hot August sun, seldom produces a good crop, and generally barely returns its seed. This fine new Japanese variety from the fact that its large blossoms form in corymbs above the berries. keeping them from being blasted by the hot sun, will produce a good crop where the old varieties will produce scarcely anything. This can be sown on oats stubble ground, from the 15th to 20th of July, with good success. As it is 12 days earlier than the common sorts. On the 24 th day of July last (very late) I furnished one peck of the Japanese to a neighbor, who sowed that day, and on September 14th harvested over 14 bushels of nice plump seed. The grain is of rich brown color, fully twice as large as the old black kind, and makes good flour. I recommend it very highly. Prices: Lb., postpaid, 30c. Peck, 50. 1/2-bus. 80c. One bus., $\$ 1.30$. 2 bus., $\$ 2.50$ Sow, $1 / 2$-bus. per acre

\section{FIELD PEAS}

CANADIAN FIELD PEAS. Valuable for North - $_{-}$ ern climates for cattle feeding. Used as feed for pigeons, etc., and for green soiling. Pk., 50c.; bu., $\$ 1.75$.

CLAY COLORED. Pk., 50c.; bu., $\$ 1.75$.

SOUTHERN BLACK=EYE COW. Also known as Sand Pea, a small white variety with black eye. Sow two bushels to the acre, Pk. 60c.; bu.; $\$ 2.00$. 
DWARF ESSEX RAPE.

There are millions of acres of good 'and that lie idle part or all of the year to run to weeds, that can be sowed to this rape and produce the finest feed imaginable and at the same time improve in fertility. It can be sown from May to September in this latitude. It can follow any other crop and furn ishes most nutritious pasture, when oftentime cattle are roaming the fields in search of a scanty living. It is particularly valuable for sheep, being twice as nutritious as red clover. In fact, sheep soon "weigh like lead" when pastured on it. It is hardy in winter, resists severe droughts; in fact, of untold value, and its cultivation is just beginning. Sow $5 \mathrm{lbs}$. per acre broadcast; $3 \mathrm{lbs}$. per acre if drilled. By mail, pkt. IOc, Ib. $35 \mathrm{c}, 3 \mathrm{lbs}$. $\$ I$. By frt. or ex., per Ib. I 5C, 100 Ibs. $\$ 9.00$.

\section{CHUFAS.}

A species of "grass nut" used to fatten hogs. It is not to be confounded with the Cocoa, or Nut Grass, for though it belongs to the same class, the Chufa is eradicated with great ease, and is never a pest. The nuts grow under the ground, very near to the surface, easily reached by pigs or poultry, and destroyed by them if they have free access. Plant in April in rows 3 feet apart and 8 to 10 inches apart in the row. If seed is dry soak before planting. One peck of seed per acre.

Pkt. I oc.; quart, 35c., postpaid. By express, quart 30c.; peck, \$I.50.

\section{LUPINS.}

Yellow. An excellent forage plant much relished by cattle, also valuable for enriching poor, sandy soil. 10 lbs. 90c, 100 lbs. $\$ 8.00$. By ex= press or freight.

\section{SPURRY.}

Grows well on dry, poor, sandy soil. Excellent for sheep and cattle. Sow from 12 to $16 \mathrm{lbs}$. on an acre. Lb. 35c, postpaid, 10 lbs. $\$ 1.20,100$ lbs. \$10.00. By express or freight.

\section{Lathyrus Sylvestris or Flat Pea.}

This wonderful plant we believe to be one of the most valuable additions to the fodder and fertilizer plants introduced in recent years, which will grow and thrive in poor sandy soils and drought-stricken districts, which but a few years ago were considered barren wastes. Analyses, of which a number have been made, show the hay to exceedingly nutritious, containing nearly double the flesh-forming ingredients in clover hay, richer than the balanced rations generally used for fattening cattle, and rich enough to fatten either hogs or sheep without the addition of grain. Being thoroughly permanent, when once established it will last 50 YEARS, and yield enormous crops of hay. 4 tons per acre have been cut in the United States at one mowing and may be mowed 2 or 3 times in a summer. Sow in drills $2 \frac{1}{2} \mathrm{ft}$. apart by 4 to 6 in. apart and 3 in. deep. The seed is slow to germinate and plants grow slowly the first season, hence must be carefully cultivated and weeds kept down. By sowing a few turnip seeds to mark the row, weeding can be done to better advantage. Roots go 10 feet into the soil. By mail, oz. 20c, $1 / 4$ lb. 50c., lb. $\$ 1.75$.

\section{BROMUS INERMIS.}

A grass of enormous value, particularly for the dry sections of the. West and south. It endures extremes of temperature and resists protracted drought, succeeding where Alfalfa fails Poor lands are no discouragement. It grows best in light, sandy loam, but its roots will penetrate the stiffest clays. It is equally good for cutting green, pasturing or curing into hay, and the dense tough sod it forms is most valuable for holding the banks of ditches and strengthening the turf of sandy soil. Dr. Sewell, of the U. S. Grass Experiment Station, Garden City, Kan., says it is equal to Timothy for cattle and horses, and makes as fine a pasture as Blue Grass. From the same station comes the report that this grass is positively the best out of over 600 kinds tested. In our country it has done equally well in Canada Mississippi, Kansas, Colorado, Wyoming and Caiifornia. Use $25 \mathrm{lbs}$ to the acre. It may be sown in the fall with winter wheat, or in the spring. Cut when first coming into bloom. By mail, lb. 40 c. By freight, bu. of 14 lbs. $\$ 3.50$.

\section{TEOSINTE.}

(Reana Luxurians.) This gigantic fodder plant from Central America somewhat reseinbles Indian Corn. It produces a great number of shoots, growing 12 feet high, thickly covered with leaves, and yielding an abundance of forage. As a soiling or fodder plant in the South and SoutlWest it surpasses either corn or sorghum, and in the extreme South is a perennial; suited also for growing in the middle latitude. When cut off will grow up again, and stools wonderfully. The leaves are long and broad and the stocks full of sweet sap. Plant sanie time as corn. $3 \mathrm{lbs}$. will plant an acre. Sow in drills $31 / 2$ to $4 \mathrm{ft}$. apart. By mail. oz. 20c., Ib. $\$ 1.50$.

\section{Soja Bean or Coffee Bean.}

The plant grows erect, $41 \frac{1}{2}$ feet high, with numerous branches covered with heavy foliage. The branches and stem are thickly set witl clusters of pods, 2 beans in a pod. The growth is very vigorous throughout the season. This seed has beon sold under the name German Coffee Berry at extravagant prices. When roasted, ground and used as coffee it resembles the genuine article quite closely. When mixed haif with coffee it is claimed by some to make a better drink than pure coffee. Its value to farmers is in the ground beans, which make a very rich feed for milch cattle and also for other stock; also valuable as a fertilizer. Sow $1 / \mathrm{b}$ bu. per acre broadcast or in drills $3 \mathrm{ft}$. apart; 12 in. between plants. By mail, pkt. 10c., pt. 20c., qt. 35c. By freight or ex= press, $1 / 4$ bu. $\$ 1.00 .$, bu. $\$ 3.50$.

\section{SUGAR CANE.}

Early Amber Cane.-This popular and well known variety is the earliest, and makes the finest quality of amber syrup and good sugar. Succeeds well from Texas to Minnesota.

Early Orange Cane.-This is the favorite va riety for molasses, from about the 38th degree of latitude, on south. It is about 12 days later than the Early A mber.

PRICES.-Postpaid of both kinds cane seed Lb. 25c. 3 ibs. 65c. By express or fast freight, Peck 60c. 1/4-bu. $\$ 1.15$. One bu. $\$ 2.25$.

\section{Improved Evergreen Broom Corn}

This variety of Imp. evergreen broom corn grows 8 to 10 feet high, stands up well, and is very free from crooked and red brush. The brush is long and fine, and always commands the highest price. I highly recommend this variety. PRICES -Lb., postpaid, 30c. By express or fast freight, peck $50 \mathrm{c}$. One bus. $\$ 165$. 5 bus. $\$ 7.50$.

\section{MILLET SEED.}

Prices subject to change of the market. We will send your money's worth.

TENNESSEE GERMAN. Seed of this wellknown sort makes much more hay in the north when the seed is grown in the south. Per bus.\$1.5?

LARGE AFRICAN MILLET. A variety of sorghum, non-saccharine, growing stalks eight to ten feet high, and yielding heads of grain ten to 15 inches long, weighing six ounces to a half pound when fully ripe. The foliage corresponds to the foliage of Amber cane. It bears dry weather and makes its crops where corn would wholly fail Plant in early April, in three foot rows, leaving one or two plants every twelve inches in the row and cuitivate as corn. Three to five pounds per acre. This variety makes the most forage, besides a large quantity of seed per acre. Not prepaid: 5 Hbs. $35 \mathrm{c}$. 10 tbs. 65 c.; 50 tbs. $\$ 2.50$.

HOG MILLET. Known also as Broom Corn Millet. Quite unlike the German and Common Millet in habit and growth as well as the appearance of the seed, which is much larger. The name Hog Millet has been applied to emphasize the use to which it is now being put as an economical and valuable food for hogs, while it is also one of the best varieties for use for bird seed and all like commercial purposes for which Millet is grown. It is a valuable help in the profitable raising of swine even in the best corn belts and of much greater value in all northern localities where corn is not so important a crop. Not prepaid. 5 lbs., 30c.; 10 lbs., $50 \mathrm{c}$. $100 \mathrm{lbs}$., $\$ 3.50$. 


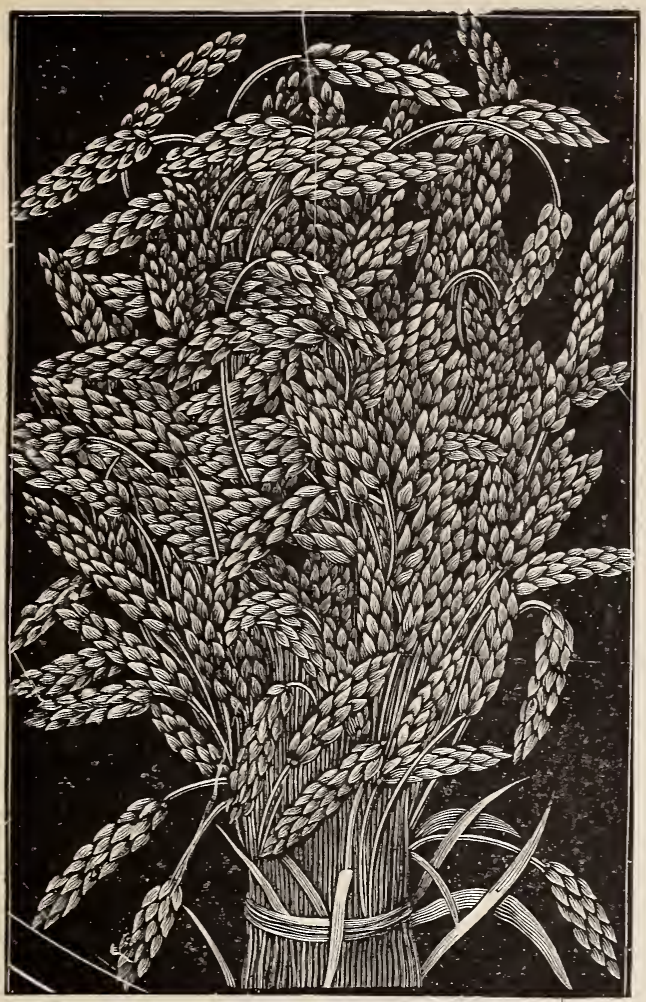

EARLY RED CLAUSON WHEAT.

The champion for black soil.

This productive and desirable brown chaff beardless, club-headed sort is destined to become a general favorite with all growers, as soon as known. Originated in that famous wheat district Genesee county, N. Y., where the great bulk of American wheat was grown before the west was opened up for cultivation. This originated from the popular Golden Cross the compact head, dark red grain, extreme hardness, rapid growth, and strong straw; and from the Clauson, baldness and red chaff, with very large kernels. It is the earliest variety of winter wheat in existence. Why run the risk of storms, excessive heat, insects and rust that are so apt to injure or destroy your wheat crop just as you feel that it is secure? The Early Red Clauson reduces the chances by coming in a week ahead of any other sort.

$\Lambda$ fter 4 years rigid testing in all parts of the country, I highly recommend this valuable new wheat for all black or rich lands, where wheat is liable to lodge. It produced, the past season, on many large fields, on nearly all varieties of soil, from 40 to 50 bushels to the acre, and on some small fields more than this. Sow one bu. per acre. Prices: 1 bu. $\$ 1.85 ; 1$ bag $21 / 1$ bu. $\$ 4.25 ; 5$ bus. $\$ 8.25 ; 10$ bus. $\$ 16$. Write for prires on larger quantities.

These wheat prices are based on the present market price of wheat, $\$ 1$ per bushel in Chicago. They are subject to changes of the market

\section{NIGGER W HEAT.}

This is one of the best bearded, stiff strawed, No. 1 milling wheats for black and brown soils. I have ever seen. Grains very long, dark and hard. A very hardy sure-crop wheat. I particularly recomniend this wheat for Southern Ind., Ky. aiid Tenn., where it has made very large yields. Sow $11 / 4$ bus. per acre. Prlce: 1 bu $\$ 1.75$; $21 / 8$ bus. $\$ 4.00 ; 5$ bus. $\$ 7.75 ; 10$ bus. $\$ 15.00$.
Tried and True, Hardy, Prolific Varieties.

As every farmer knows, we have been much in need of Sure Crop, Stiff Strawed, Firm Chaff, Good Milling, Early Hardy varieties of $\mathbf{w}$ heat. That would :o through repeated freezing and thawing unhurt, yield full crops of extra quality, and sell at top prices. It is largely to your interest to grow the hardy, prolific, good milling wheats. How many farmers in your locality grow such wheat? Are they not in the habit of clinging to the old run out, unproductive sorts? You perhaps know of farmers who are an exception to this. They have been changing their seed. And are perhaps ready to do so again. Who if you will call their attention to it, will be anxious to help form a club for new seed wheat, this fall. I received one such club order for $\$ 2 \% 6.00$. See next page.

Mr. C. A. Pillsbury, of Minneapolis. Minn., the most extensive miller in the world, recently said: "I do not think the wheat situation warrants any foreboding of evil. In this country, con sumption of wheat is increasing about 8 million to 10 million bushe's annually against a decreasing supply. In the next 5 years the great mills in Minnea polis, will grind more wheat at over $\$ 1$ per bushel, than under that price.

According to a table published by the Chicago Board of Trade, the average price of wheat for the past 32 years, his been over $\$ 1.10$ per bushel. And for past 6 years, $823 / 4 \mathrm{c}$ per bu. It pays big to get your seed from a distant locality. Even if it is but the same variety you have been raising.

\section{EARLY RIPE WHEAT.}

This is a smooth wheat, red chaff. The straw is short and strong, stands up well on rich land. It is a very early wheat, and is not liable to rust or scab. The grain is round, plump and heavy and makes a first-class milling wheat. PRICES: One bu. $\$ 1.80 ; 2 \frac{1}{2}$ bus. $\$ 4.10 ; 5$ bus. $\$ 8.00$ : 10 bus, $\$ 15.50$.

\section{HARVEST KING WHEAT.}

This is a smooth red chaffed wheat, very similar to the Pool. It has a very stiff straw and is well adapted to strong, rich land. It is ex. tremely hardy, in fact, $\mathbf{I}$ regard it as one of the hardiest and best wheats in the country. During the past three years we have had almost a failure of winter wheat in many localities, but the Harvest King has stood the test better than any other variety, and given in almost every case a fair average yield. Our seed is free from rye, cockle or chess. Prices: Same as for Early Ripe.

\section{JONES' WINTER FIFE.-(Smooth.)}

Chaff white, with a velvet-like glisten in the sun. Kernels very hard, dark and transparent presenting the same dark look when cut. From the dense nature of the grain it will weigl from 4 to 6 pounds more to the measured bushel than common sorts. It is especially desirable for rich, strong soils, producing an abundant yield of heavy, plump grain, requiring to be left until fully ripe before harvesting, as it does not easily shell in the field, and the seed improves in color.

Prices: Same as for Early Ripe.

Bags: Remit 15c for a new seamless bag, in which to ship each two bushels or less, that you order. 
I earnestly request $y$ ou to write these parties, enclosing stamped envelope to insure their rep!y. If good reference be given me for their safe and hasty return, I will send original testimonials of any here printed, in their officially dated and post marked envelopes, to any who desire to see them. A pleased and satisfied customer is my best advertisement.

Mr. Geo. Berry, Dawson, Sangamon county, Ill., writes: "The corn I got from you was the hest investment I ever saw on the farm. If you can beat it, you will have a dandy, sure

Mr. Henry Roselius, Corning, Holt Co., Mo., writes: "Your yellow and white corn made 65 and 0 bus. per acre respectively, for me this year. Myself and neighbors think it the best corn we ever saw Have sold all I have to spare."

Mr. L. Stowe, Spirit Lake, Dickinson Co., Ia., writes: "Your corn is the finest I ever saw. Much pleased with it, and with your way of dcing business."

Mr. G. P. Orendorff, Lacon, Morgan Co., Ala., writes: "Your corn made an excellent yield for me this year, considering our great drouth. I like your style of doing business.'

Mr. J. Baxter Allen, Anniston, Ala., writes: "I like your Hickory King Corn. It is early, prolific, and almost weavil proof. It made a fine yield for me."

Mr. Robert F. Fisher, Epperson, McCracken Co., Ky., writes: "Your corn yielded as much on our poorest ground this year, as our native corn did on our very best land. Myself and neighbors like it very much, because it matures ahead of early drouth."

Mr. C. B. Cheatham, Murphy, Collin Co., Tex., writes: "Your Champion Yellow Dent Corn made 37 bus. of nice corn per acre, in 95 days from planting, or just 30 days before the drouth struck my native corn. My native corn being so much later, the severe drouth caught it while in the milky stage, and reduced its yield to $2 \%$ bus. of smutty corn per acre. I have made $\$ 26.00$ clear on the half bushel of your corn, this year, over what I would have made had I planted all native corn. I have none for sale.

Mr. A. Elder, Princeton, Franklin Co., Kan., writes: "Your Champion Yellow Dent Corn is two weeks earlier than, and will make 10 bus. per acre more than our native corn alongside. I will plant all of this kind next spring."

Mr. Wm. Roe, Vinland, Douglass Co., Kan., writes: "The 3 tos. of your Champion Yellow Dent Corn matured its large, even, deepgrained, small cobbed ears, in 95 days from planting, and promises a large yield. Myself and neighbors are well pleased with it."

Mr. J. W. Ford, Huntington, Ind., writes: "I planted your extra early yellow corn on June 4th. It fully matured in 90 days. I am much plcascd witl it."

Mr. John J. Page, Sparks' Hill, Hardin Co Ill., writes: "Your corn far surpassed in yield my best native corn. I believe it is a very valuable corn for all localities subject to chintz bugs. As it matures before they begin damaging our native corn."

Mr. D. T. Elston, Crandall, Coffee Co., Kan., writes: "Your Champion Yellow Dent Corn was the best corn in this country (hot winds streak), this year, yielding 25 bus. per acre. While my native corn yielded but 18 bus. per acre-same kind of ground, same care and cultivation. I want more seed from you next spring."

Mr. E. D. Sappington, Nelson, Saline Co., Mo., says: "I take pleasure in informing you that
I am satisfied that my yield per acre has been increased at least $1 / 3$ by raising your $C$. W. Pearl corn. I fully endorse your way of doing business."

Mr. W. H. Allan, Craig, Holt Co., Mo., says: "The Golden Beauty corn I bought of you, was planted May 21st. Ripened in good order and yielded 63 bus. per acre. It is liked on account of its large smooth ears, and its being free from suckers. I sold nearly all of it that 1 raised, to my neighbors, for seed."

Mr. F. H. Mueller, Linn's Mills, Lincoln Co., Mo., says: "I have had fine success with all of your seeds. Monarch Rice pop corn is fine, and of excellent flavor. You have a first-class way of doing business."

Mr. Homer Triboulet, Nauvoo, Hancock Co., Ills., says: "Your seed corn was the finest I have ever received from any seed house. Your Blount's Prolific is a splendid fodder corn, and its ears matured all right. I am well pleased with the way yon do busincss."

Mr. Milton T. Ashley, Hopeville, Clarke Co., lowa, says: "I planted your Champion Yellow Dent Corn May 1\%th. It is now ripening. I consider it a big yielder. And think you are an honorable dealer.'

Mr. J. W. Potter, North Buena Vista, Ia., $(80$ miles further north than Des Moines). writes: "I am well pleased with your Champion Y. Dent Corn. It will make about 75 bus. per acre, of good sound corn, for me this year."

Mr. J. B. Piersol, Rockwell P. O., in Northern Jowa, says: "The Improved Leaming corn that I purchased from you last spring, made me 62 bus. per acre. Which was better than any of our corn from other seed. It is early, good sized ears, kernels very compact on the cob, strong, sweet, and very oily. Stalks are very strong, and stood well. I attribute the extra yield, to the change of seed which I have always found to be of great advantage. I have no seed to spare.

Mr. Lewis S.Walworth, Jerome, Hillsdale Co. Mich., says: "The Champion White Pear" corn that I got of you last year, did splendidly for me. I measured off 234 acres and paid for husking 372 bus. of it. Or a little over 118 bus. per acre."

Mr. J. M. McCrary, Comanche, Comanche Co. Tex., says: "The Champion Yellow Dent Corn you sent me last spring, did well for me. It made good corn alongside of our native corn that made scarcely anything, on account of our early and severe drouth.'

Wm. M. Lochart, St., Henderson, Ky., says: "I like your Champion Yellow Dent Corn very much. Fine large ears, which will make all of 80 bus. per acre, on ordinary land."

Henry Hendricks, Chambersburg, Pike Co. Ill., says: "My Fultz wheat yielded 10 bus. per acre. Myswamp wheat 16 bus. while the wheat which I bought of you, yielded 30 bus. per acre. I have sold all I have to spare, to $\mathrm{my}$ neighbors, for seed. Could have sold 1,000 bushels of it.

50 Bushels per Acre. Mr. Solomon Shattel, Rossville, Vermilion Co, Ill., says: "The wheat I bought of you, made 50 bus good wheat per acre for me, by machine measure. My neighbors like the wheat, but I have none to sell at any price."

It is with renewed confidence in the superiority of my seeds, and greater assurance of my ability to render your investments in my seeds, as profitable and satisfactory to you, as theirs have been to them, that I agaln solicit your patronage, Believing that now is the time when they should have your careful attention. Yours very truly, 